\title{
Tracheal avulsion in a cat
}

\author{
Rafaela da Silveira Prestes ${ }^{*}$ (iD) Flaviani Emilia dos Santos ${ }^{2}$ \\ Izabela Patrício de Souza ${ }^{1}$ Sóstenes Apolo Correia Marcelino ${ }^{1}$ Renato Cesar Sacchetto Torres ${ }^{3}$ \\ Christina Malm ${ }^{3}$ Patrícia Maria Coletto Freitas ${ }^{3}$ Suzane Lilian Beier $^{3}$ Roselene Ecco $^{3}$ iD \\ Anelise Carvalho Nepomuceno ${ }^{3}$
}

${ }^{1}$ Departamento de Clínica e Cirurgia, Programa de Pós-graduação em Ciência Animal, Universidade Federal de Minas Gerais (UFMG), 31270-901, Belo Horizonte, MG, Brasil. E-mail: rafaelasprestes@gmail.com. *Corresponding author.

${ }^{2}$ Hospital Veterinário, Escola de Veterinária, Universidade Federal de Minas Gerais (UFMG), Belo Horizonte, MG, Brasil. ${ }^{3}$ Departamento de Clínica e Cirurgia, Universidade Federal de Minas Gerais (UFMG), Belo Horizonte, MG, Brasil.

ABSTRACT: Tracheal avulsion is a condition seen in small animals and occurs as a result of a traumatic incident to the cervical and/or thoracic regions. The aim of this study is to report a case of tracheal avulsion in a cat using imaging examinations for diagnostic investigation. In this report, we examined an eight-month-old male, cat of undefined breed, diagnosed with tracheal avulsion using complementary imaging tests. This diagnosis was confirmed with post-mortem examination. Radiographic examination of the patient's thorax and a tracheoscopy were performed. These examinations revealed complete discontinuity of the tracheal circumference, the presence of focal and circumscribed dilation of the tracheal lumen and stenosis. The patient quickly died without clinical and surgical intervention. Macroscopic analysis revealed a tracheal diverticulum confirming the findings of the imaging tests. The use of radiographic examinations in conjunction with tracheoscopy was effective at diagnosing this condition.

Key words: Diagnostic imaging, trauma, trachea, veterinary pathology, domestic cat.

Avulsão traqueal em um gato

RESUMO: A avulsão traqueal é uma condição identificada em pequenos animais e ocorre como resultado de um incidente traumático na região cervical ou torácica. O objetivo deste trabalho consiste em relatar um caso de avulsão traqueal em um felino doméstico submetido a exames de imagem para investigação diagnóstica. Um felino, macho, sem raça definida, de oito meses de idade, foi diagnosticado com avulsão traqueal por meio de exames complementares de imagem e com confirmação diagnóstica por exames post mortem. O paciente foi submetido a exames radiográficos do tórax e traqueoscopia. Os achados dos exames de imagem revelaram completa descontinuidade da circunferência traqueal, presença de dilatação focal e circunscrita do lúmen traqueal e estenose. O paciente morreu e não houve tempo hábil para intervenção cirúrgica. Na análise macroscópica identificou-se um divertículo traqueal, confirmando assim, os achados dos exames de imagem. A utilização dos exames radiográficos em conjunto com a traqueoscopia foi efetiva no diagnóstico dessa condição.

Palavras-chave: Diagnóstico por imagem, trauma, traqueia, patologia veterinária, felino doméstico.

\section{INTRODUCTION}

Tracheal avulsion is a condition considered to be the result of a traumatic incident to the cervical or thoracic regions or in both. One of the probable causes of tracheal avulsion is hyperextension of the head and neck (BHANDAL \& KUZMA, 2008 and NELSON, 1993). This condition presents a high mortality rate due to the risk of hypertensive pneumothorax, mediastinal and cervical emphysema, as well as stridor and respiratory distress. Teams who manage these cases are usually multidisciplinary, as they normally involve intensive care specialists, anesthesiologists and surgeons (COSTACHE et al., 2004). After rupture of the tracheal cartilage by avulsion, it is possible for the lumen to be maintained by the adventitious layer, if it remains intact. Another possible way for the tracheal lumen to be maintained could be through thickening of the mediastinal tissue, which may lead to the development of pseudotrachea (WHITE et al., 1995). The late development of respiratory clinical signs may be related to the degree of tracheal stenosis and lumen obstruction (BERKWITT \& BERSON, 1895). It is important to consider that most veterinary patients are seen one to three 
weeks after the traumatic event. After this period, signs of pneumomediastinum, pneumothorax and soft tissue edema may be in the resolution phase (MACREADY et al., 2007). Cervicothoracic radiography is the auxiliary method for diagnosing this alteration. Radiographic signs that characterize tracheal avulsion may be associated with an area of well-defined focal dilatation, which is surrounded by a thin margin of soft radiopaque tissue, representing the intact tracheal adventitia (THRALL, 2014). Tracheoscopy has been described in medical studies as a reliable and frequently used method to locate the region of tracheal lesions (DANCER et al., 2018), and may even be confirmatory in some cases (BHANDAL \& KUZMA, 2008). Here, we described a case of tracheal avulsion in a domestic cat using radiographic examinations in conjunction with tracheoscopy.

\section{Case report}

An eight month- old, undefined breed male cat, with access to the street was referred to a Veterinary Hospital, with a history of respiratory distress. During clinical examination, the patient presented severe inspiratory dyspnea and cyanosis. The patient was referred to the Intensive Care sector for stabilization. After clinical improvement, this patient was referred to the radiology sector to perform complementary exams. During radiographic examination, lateral right and left side projections of the thorax were performed. During the analysis of the images, alterations of the tracheal lumen at the 5 th intercostal space were noticed. These alterations included a complete discontinuity of the tracheal circumference, with an area of localized focal dilatation also visible. This was seen radiographically as the formation of an air diverticulum surrounded by fine soft tissue radiopacity (Figure 1A). A tracheoscopy was requested for diagnostic clarification. The examination revealed severe tracheal stenosis in the pre-carina segment (Figure 1B). A tomographic examination was considered, but it was not available at the moment of the patient's care. After performing the imaging tests, the patient quickly unbalanced and died, leaving clinicians and surgeons with no time to perform surgical interventions. The patient was referred to the Veterinary Pathology Sector for necropsy. Macroscopic examination revealed marked cyanosis. In the trachea, $3.5 \mathrm{~cm}$ cranial to carina, corresponding to the space between the $3 \mathrm{rd}$ and 5 th ribs, there was an area of $1.5 \mathrm{~cm}$ with absence of the upper lateral portions of the cartilaginous semi rings. In the topographic region of the tracheal membrane, a diverticulum with a diameter of $0.2 \mathrm{~cm}$ was present (Figure 2A). When the lumen was injected with air, this area was visualized in a saccular format (Figure 2B). The tracheal lumen of this site was markedly stenosed, measuring $0.3 \mathrm{~cm}$ in diameter. The lumen of the cranial portion measured $0.8 \mathrm{~cm}$ in diameter and the caudal portion $0.7 \mathrm{~cm}$ in diameter. In the lung there was intense multifocal emphysema. Histopathological examination revealed no cartilaginous tissue in the wall of the trachea corresponding to the area of stenosis. The wall consisted of muscle cells in a thin, single layer of preexisting muscle fibers that disappeared in the central region of the stenosis area.

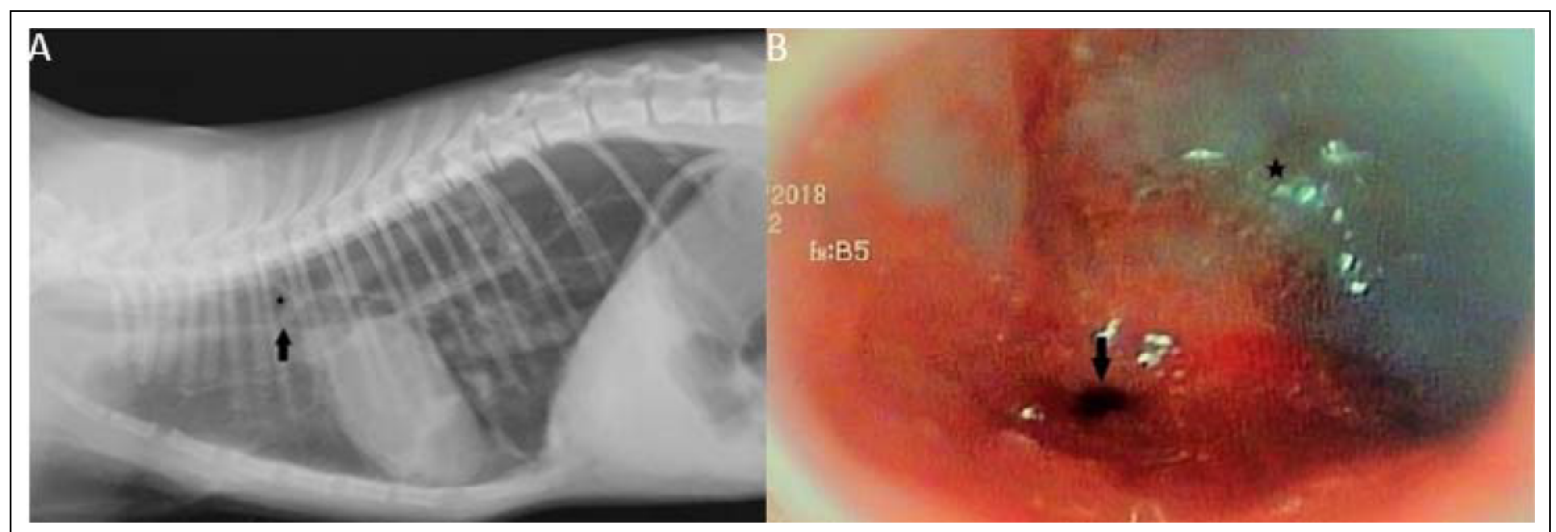

Figure 1 - A: Right lateral radiographic image of the thorax of a domestic feline demonstrating tracheal sacculation (asterisk) anterior to the region of tracheal stenosis (arrow). B: Tracheoscopy image of a feline with marked tracheal stenosis (black arrow) and segmental sacculation anterior to carina (asterisk). 


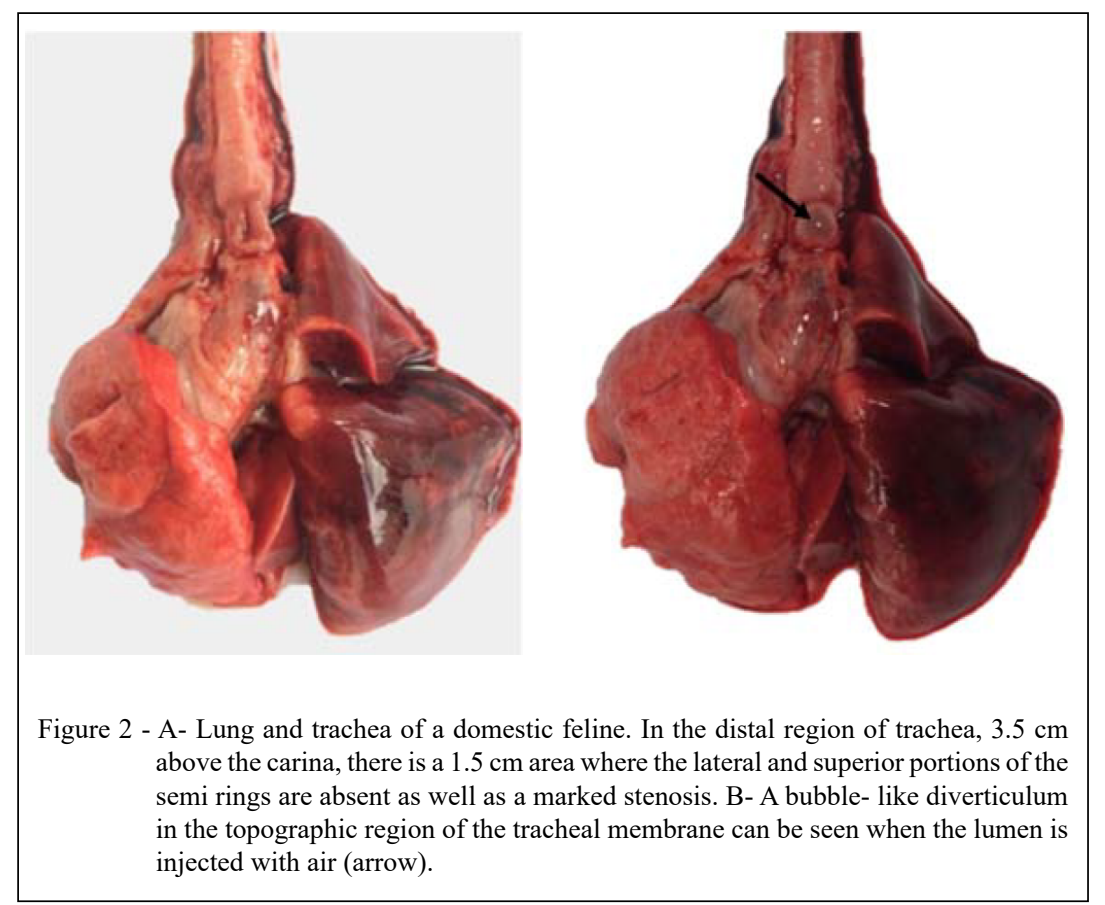

\section{DISCUSSION}

Radiographic findings commonly reported in cases of tracheal avulsion are usually associated with predisposing conditions, such as stenosis and tracheal diverticulum formation. These findings are similar to those reported in the present report, where there was narrowing of the tracheal lumen in both complementary exams. The findings from the trachea were similar to those described in the literature (WHITE, 2000). Radiographic signs that characterize avulsion may be associated with the discontinuity of the tracheal circumference about 1 to $4 \mathrm{~cm}$ cranial to carina, resulting in a welldefined focal dilation surrounded by a thin margin of radiopaque soft tissue. This change is called pseudo air way (MACREADY et al., 2007). In cases of clinical or radiological suspicion of tracheobronchial alteration, the additional evaluation with computed tomography (CT) is of great importance, since the appearance and location of the lesions appear more accurately on CT when compared to x-ray. Changes in the parenchyma and the correlation with clinical data may enable the differential diagnosis between diffuse tracheal alterations (MARCHIORI et al., 2008). Recent scientific articles have found CT to be the most advanced imaging method used to access tracheal disorders in felines (BARLETTA et al., 2015; SAYRE et al., 2016). However, this method was not available at the time of this case. Studies have shown that necropsy findings may include mucosal ulcers, inflammation, mucosal and submucosal edema, as well as hemorrhagic lesions. In the histopathological examination of some human patients it was possible to verify tracheal cartilage necrosis (STAUFFER et al., 1981); although, these findings were not observed in our case. The surgical management of the intrathoracic tracheal avulsion can be promptly performed through right lateral thoracotomy. Careful anesthesia should be considered for good surgical results. Intrathoracic tracheal resection and anastomosis may also be performed in an attempt to correct tracheal avulsion (WHITE, 2000). However, none of the surgical techniques were performed due to the patient's critical clinical state.

\section{CONCLUSION}

Studies have reported advanced imaging techniques, such as computed tomography, as reliable diagnostic tests. In the present case, radiographic examination in conjunction with tracheoscopy was effective at diagnosing a case of tracheal avulsion in a cat, later confirmed by macroscopic and microscopic examinations.

Ciência Rural, v.49, n.10, 2019. 


\section{ACKNOWLEDGEMENTS}

This article was financed in part by the Coordenação de Aperfeiçoamento de Pessoal de Nível Superior (CAPES), Brasil, with the aid of scholarships.

\section{DECLARATION OF CONFLICT OF INTERESTS}

The authors declare no conflict of interest. The founding sponsors had no role in the design of the study; in the collection, analyses, or interpretation of data; in the writing of the manuscript, and in the decision to publish the results.

\section{AUTHORS' CONTRIBUTIONS}

The authors contributed equally to the manuscript.

\section{REFERENCES}

BARLETTA, M., Anesthesia Case of the Month. Journal of the American Veterinary Medical Association, v.247, n.5, p.488491. 2015. https://doi.org/10.2460/javma.247.5.488.BHANDAL, J.; KUZMA, A. Tracheal rupture in a cat: diagnosis by computed tomography. The Canadian Veterinary Journal, v.49, n.6, p.595, 2008. Available from: $<$ https://www.ncbi.nlm.nih.gov/pmc/ articles/PMC2387268/>. Accessed: Oct. 20, 2018.

COSTACHE, V.S.; RENAUD, C.; BROUCHET, L.; TOMA, T.; LE BALLE, F.; BERJAUD, J.; DAHAN, M. Complete tracheal rupture after a failed suicide attempt. The Annals of thoracic surgery, v.77, n.4, p.1422-1423, 2004. Available from: <https:// doi.org/10.1016/S0003-4975(03)01273-6>. Accessed: Oct. 12, 2018. doi: 10.1016/S0003-4975(03)01273-6.

DANCER, S.C.; VAN DER ZEE, J.; KIRBERGER, R.M. Computed tomographic findings in a Bluetick Coonhound with a longitudinal thoracic tracheal tear. Veterinary Radiology \& Ultrasound, p.1-5, 2018. Available from: <https://doi.org/10.1111/ vru.12607>. Accessed: Oct. 15, 2018. doi:10.1111/vru.12607.
MARCHIORI. E.POZES. A. S. JUNIOR A. S. ESCUISSATO, D. L. IRION K. L., DE ARAUJO NETO.C. \& ZANETTI.G. Alterações difusas da traquéia: aspectos na tomografia computadorizada. Jornal Brasileiro de Pneumologia, vol.34, n.1, p.47-54. 2008.

MACREADY, D. M. JOHNSON, LYNELLE R; POLLARD, RACHEL E. Avaliação fluoroscópica e radiográfica do colapso traqueal em cães: 62 casos (2001-2006). Revista da American Veterinary Medical Association, v.230, n.12, p.1870-1876, 2007.

NELSON, A.W. Lower respiratory system. In: SLATTER, D.H. (Ed). Textbook of small animal surgery. London: Saunders, 1993. Cap.55, p.777-804.

STAUFFER, J.L.; et al. Complications and consequences of endotracheal intubation and tracheotomy: a prospective study of 150 critically ill adult patients. The American journal of medicine, v.70, n.1, p.65-76, 1981. Available from: <https://doi. org/10.1016/0002-9343 (81)90413-7>. Accessed: Nov. 15, 2018. doi: $10.1016 / 0002-9343(81) 90413-7$.

SAYRE, R. S., et al. Traumatic tracheal diverticulum corrected with resection and anastomosis during one-lung ventilation and total intravenous anesthesia in a cat. Journal of veterinary emergency and critical care, vol.26, n.6, p.864-869. 2016.

THRALL, D.E.; ALEXANDER. K.; Faringe, Laringe e traqueia. In: DONALD, E.; THRALL, D.E. (Ed). Diagnóstico de Radiologia Veterinária. Rio de Janeiro: Elsevier, 2014. Cap.26, p.495-496.

WHITE, R.N.; MILNER, H.R. Intrathoracic tracheal avulsion in three cats. Journal of Small Animal Practice, v.36, n.8, p.343-347, 1995. Available from: <https://doi.org/10.1111/j.1748-5827.1995. tb02945.x>. Accessed: Nov. 14, 2018. doi: 10.1111/j.1748-5827. 1995.tb02945.x.

WHITE, R.N.; BURTON, C.A. Surgical management of intrathoracic tracheal avulsion in cats: long-term results in 9 consecutive cases. Veterinary Surgery, v.29, n.5, p.430-435, 2000. Available from: <https://doi.org/10.1053/jvet.2000.9138>. Accessed: Nov. 14, 2018. doi:10.1053/jvet.2000.9138. 